\title{
Blasting technique for stabilizing accident- prone slope for sustainable railway route
}

\author{
N. K. Bhagat ${ }^{1, *}$, A. K. Mishra ${ }^{2}$, M. M. Singh ${ }^{1}$, Aditya Rana ${ }^{1}$, S. Tewari ${ }^{1}$ and \\ P. K. Singh ${ }^{1}$ \\ ${ }^{1}$ CSIR-Central Institute of Mining and Fuel Research, Barwa Road, Dhanbad 826 015, India \\ ${ }^{2}$ Indian Institute of Technology (Indian School of Mines), Dhanbad 826 004, India
}

Konkan Railway has many unstable slopes along the $741 \mathrm{~km}$ long route from Roha to Thokur in the states of Maharashtra, Goa and Karnataka in India. Frequent cases of boulder fall, slope failure and landslide used to occur on the track during the rainy season. Such cases have resulted in several severe train accidents, traffic interruptions, loss of lives and assets. Hence the Konkan Railway Corporation deployed several geotechnical measures such as wire-netting, retaining wall, rock bolting and shotcreting for stability enhancement. However, none of these measures proved effective and accidents continued. Finally, the Konkan Railway Corporation decided to redesign the cut-slopes using blasting. Excavation of hard rock for its removal without damaging the existing track (2$3 \mathrm{~m}$ away from the slope) and disrupting the traffic, was a daunting task. An unplanned blast would have resulted in the closure of the route for hours. The present study explains the method in which entire cutting was redesigned by formation of 5 to $2 \mathrm{~m}$ wide berms at an interval of $6 \mathrm{~m}$ bench height from rail track level using novel direction controlled blasting technique. Further, stability of the cut-slope, before and after exacavation, has been determined using kinematic analysis and 3D numerical modelling. Similar technique can be adopted to widen or stabilize an active transportation route in hills.

Keywords: Blasting, kinematic analysis, numerical modelling, railway track, slope rockmass removal, stabilization.

SLOPE failure or boulderfall is a frequent incident on a transportation route often leading to disasters ${ }^{1-4}$. Ersoz and Topal $^{5}$ reported that cut slopes have a high probability of failure due to disturbance of original geometry and reduced strength. The state of California conducted a comprehensive study to investigate the reasons of rockfalls on highways. Twelve causes for boulder fall were reported such as rain, freeze-thaw, fractured rock, wind, snow melt, channelled runoff, adverse planar failure, burrowing by animals, differential erosion, tree roots,

*For correspondence. (e-mail: nkbhagat@cimfr.nic.in) springs or seeps, wild animals, truck vibrations and soil decomposition ${ }^{6,7}$.

The necessity of treatment and maintenance of unstable slopes along transportation routes was felt long ago ${ }^{2,8-10}$. There are several methods which are being used today to prevent slope failures. They are broadly classified into two categories: (i) reinforcement and (ii) rock removal. The reinforcement category includes rock bolting, shotcreting, buttressing, concreting with bolting, doweling, wire-netting with anchorage and drainage system. Rock removal includes trimming, re-sloping and scaling of unstable slope $\mathrm{e}^{2,11,12}$. Application of reinforcing measures to stabilize slope for long-term is limited. Slope instability situations were encountered at many locations along the Konkan Railway (KR) route. The rail line was laid through undulating and extremely rugged terrain of Western Ghats to maintain level run. It is one of the most significant and challenging infrastructure projects undertaken in independent India. The project was completed in eight years and train service on a full section of $741 \mathrm{~km}$ route from Roha in Maharashtra to Thokur in Karnataka was commissioned on 26 January 1998.

Use of drilling and blasting method is the most common practice to break the hard rock in mining, quarrying and civil construction projects. Explosive is the cheapest means of breaking the rock. However, its use is associated with environmental hazards such as ground vibration, fly rock, noise and back break. Heavy blasting without perimeter control causes fractured slope facet and is undesirable for long-term stability. Significant cause of unstable rock cuttings along the KR route was the ignorance of perimeter controlled blasting during initial excavation. Torrential rainfall during rainy season aggravated the problem. KR adopted various geotechnical measures to strengthen unstable rock cuttings. However, recurring boulder fall and slope failures necessitated redesign of the vulnerable cuttings using blasting technique.

The authorities of KR approached the authors to design excavation sequence and blasting technique in such a manner that regular train operations should not get affected. According to the guidelines framed by the Ministry of Railways (India) in 2005, the permissible slope ratio should be $0.25: 1$ for hard rock, $1: 1$ for weathered 


\section{RESEARCH ARTICLES}

rock and strata with soil-mixed boulders ${ }^{13}$. These guidelines were followed during the excavation work. Benching is the most popular method of breaking the slope for stabilizing it. Benching changes the appearance of high-rise slopes by providing 2 to $5 \mathrm{~m}$ wide berms at a height of 6 to $8 \mathrm{~m}$. The bench width and height is varied in accordance with the strata, availability of land and stability analysis. Implementing blasting to remove the rock mass can be challenging, especially near permanent structures like a railway track. The main concerns were to control the extent of the muck-throw towards the track and limit the intensity of ground vibration to prevent triggering of the slide. Moreover, the distance travelled by a fly rock during blasting had also to be controlled for averting damage to the track.

Before excavation, kinematic analysis was conducted for ascertaining the mode of failure and determining safe slope angle. Further, three-dimensional numerical modelling of pre- and post-excavation was done using Finite Difference Method (FDM) in Fast Lagrangian Analysis of Continua (FLAC 3D) to evaluate the factor of safety (FoS). In this article, a novel direction-controlled blasting technique for removing an unstable slope at Talegaon II of KR is discussed. The stated technique has been implemented on 101 unstable slopes without disturbing the routine train traffic.

\section{Study area}

Talegaon II cutting was excavated in 1994-95 and is one of the 564 cuttings along KR. It is situated between Sindhudurg and Kudal railway stations in the Ratnagiri section of Maharashtra (Figure 1). It is located between $\mathrm{CH} 334+100$ and $\mathrm{CH} 334+470 \mathrm{~km}$ in Sindhudurg district and is $30 \mathrm{~km}$ away from the famous tourist place Sindhudurg Fort. The rock mass is mainly of Deccan Trap Formation of late Cretaceous to early Eocene age ${ }^{14}$. The strata consists of rock and soil-mixed boulder cutting with varying depths $(10-22 \mathrm{~m})$ on either side of the track. Top of the cutting on either side of the rail track was occupied by $5-8 \mathrm{~m}$ thick soil mixed bouldery strata. The middle part was composed of slightly weathered basalt of 1-2 $\mathrm{m}$ thickness. The bottom part of the cutting was composed of 8-12 m thick blocky, irregular basalt with varying structural and physicomechanical characteristics. More than three joint sets were noted in the rock mass with chlorite as filling material. The area receives heavy rainfall (1700 to $4900 \mathrm{~mm}$ annually) during southwest monsoon from the last week of May up to September. It was noted that high precipitation washes out joint filling material leaving the boulders loosely attached to the slope face. Uncontrolled blasting (using $115 \mathrm{~mm}$ diameter hole) conducted to excavate the rock mass during the initial phase of railway construction led to the formation of deep cracks penetrating the slope. Absence of half-cast barrel marks on exposed faces further confirmed this inference. Numerous fractures oblique and parallel to the track are visible on the slope. The depth of blast-induced fractures varied between 2 and $3 \mathrm{~m}$. These circumstances resulted in localized rock mass failures and boulder falls on the track. On 22 July 2011, around $500 \mathrm{~m}^{3}$ soil and $200 \mathrm{~m}^{3}$ rock mass fell over the track, breaching the protecting net that had been installed earlier and disrupted the rail traffic for considerable time. Trains were terminated, cancelled and passengers were transhipped to different stations. After the failure, KR decided to redesign the cutting. Before excavation, a detailed geological investigation was conducted to determine the safe slope angle.

\section{Stability analysis for determining the safe angle of slope}

Discontinuities play an important role in the stability of a slope. Dominant joints sets, joint spacing, persistence, aperture, joint roughness, gauge, weathering grade and

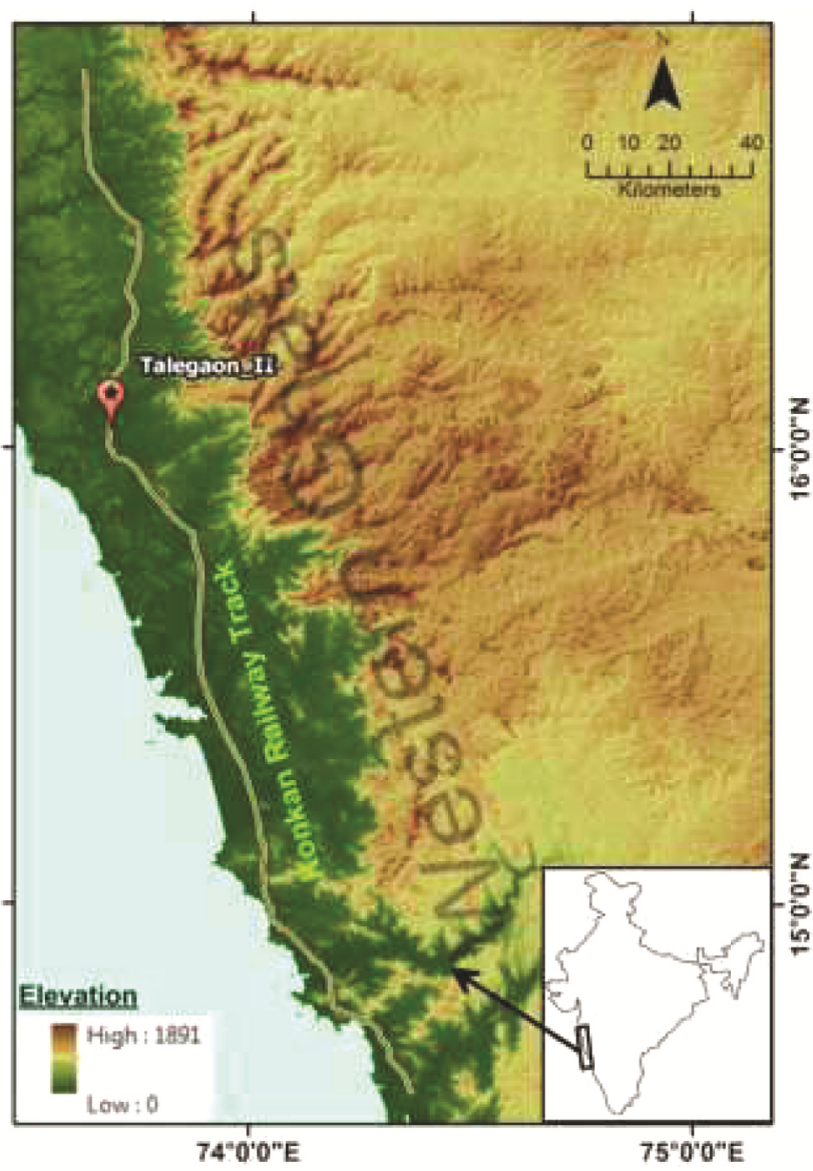

Figure 1. Location of Talegaon II hill cutting along $\mathrm{KR}$ route (Source: ASTER DEM (30 m resolution) through US Geological Survey). 



Figure 2. $\boldsymbol{a}$, Kinematic analysis for planar failures. $\boldsymbol{b}$, Kinematic analysis for wedge failures.

Table 1. Type of slope failures and its probability of occurrence

\begin{tabular}{lcccc}
\hline Site & Slope orientation $\left(^{\circ}\right)$ & Joint set and orientation $\left(^{\circ}\right)$ & Type of failure & Kinematic probability (\%) \\
\hline East slope & $95 / 82$ & J1: $315 / 65$ & Planar & 66.67 \\
& & J2: $350 / 75$ & Wedge & 100 \\
\hline
\end{tabular}

groundwater condition of the rock mass were studied for modelling the slope. The data on joints were plotted in a stereographic net and analysed using DIPS software. The intersection of the discontinuity plane with slope face produced an image of potential planar and wedge failures (Figure $2 a, b)$. The results of the analysis are summarized in Table 1. Rock quality designation (RQD) value was observed between $50 \%$ and $90 \%$ on the exposed slope face ${ }^{15,16}$. Geo-mechanical properties of intact rock samples were calculated in accordance with the IS Code 11315 (part 5) ${ }^{17}$ to calculate rock mass rating (RMR) value. The rock samples were tested in the laboratory for evaluating strength parameters (density, uniaxial compressive strength (UCS), tensile strength, Young's modulus, Poisson's ratio). Table 2 gives the rock mass properties of cut-slope, such as geological strength index 
Table 2. Parameters used to determine rock mass properties

\begin{tabular}{|c|c|c|c|c|c|c|c|c|c|c|c|c|}
\hline Type of strata & $\begin{array}{l}\text { Bulk density } \\
\qquad\left(\mathrm{kg} / \mathrm{m}^{3}\right)\end{array}$ & $\begin{array}{c}\text { UCS } \\
(\mathrm{MPa})\end{array}$ & $\begin{array}{c}\text { Tensile strength } \\
(\mathrm{MPa})\end{array}$ & $\begin{array}{l}\text { Young's modulus } \\
\text { (MPa) }\end{array}$ & $\begin{array}{l}\text { RQD } \\
(\%)\end{array}$ & $\begin{array}{l}\text { Poisson's } \\
\text { ratio }\end{array}$ & RMR & GSI & $m_{i}$ & DF & $\begin{array}{c}C \\
(\mathrm{KPa})\end{array}$ & $\Phi\left({ }^{\circ}\right)$ \\
\hline Basalt & 2625 & 61 & 5.7 & 7740 & 65 & 0.22 & 59 & 59 & 25 & 1 & 2.783 & 29 \\
\hline Soil-mixed boulder & 1925 & $<1$ & - & - & - & 0.33 & - & - & - & - & - & - \\
\hline
\end{tabular}

UCS, Uniaxial compressive strength; RQD, Rock quality designation; RMR, Rock mass rating; GSI, Geological strength index; $m_{i}$, Material constant; DF, Disturbance factor; $C$ Cohesion; $\Phi$, Angle of internal friction.

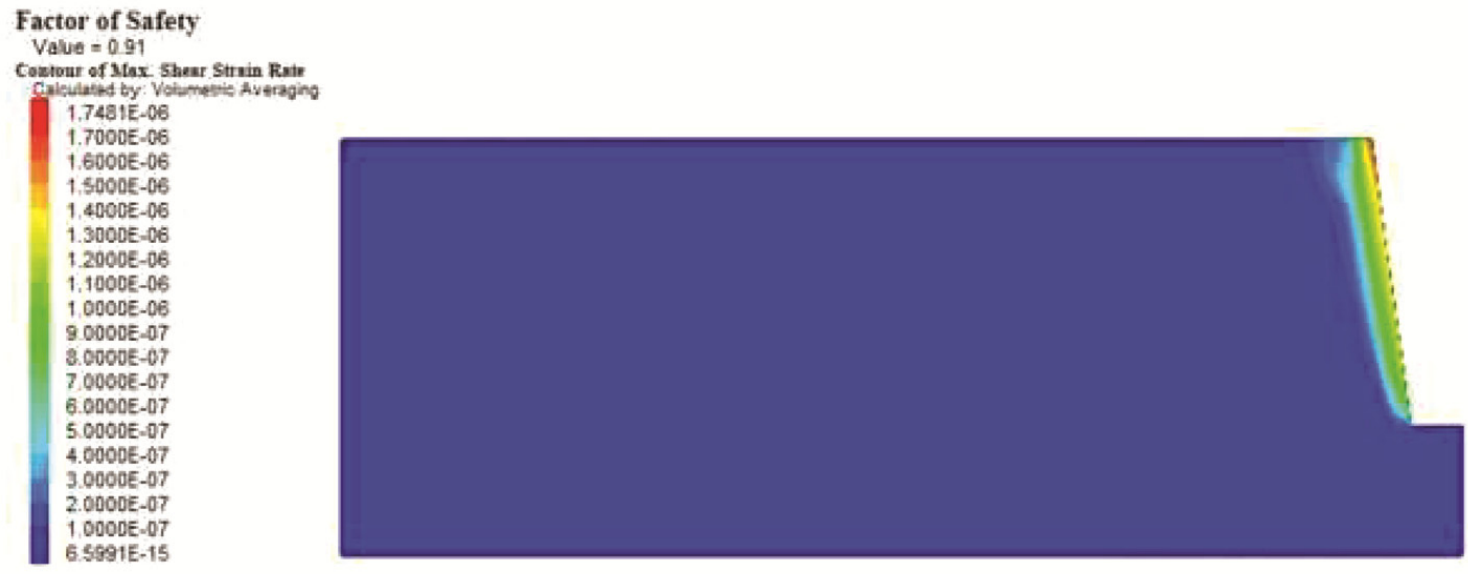

Figure 3. FLAC 3D model signifying the maximum shear strain rate and failure zones.

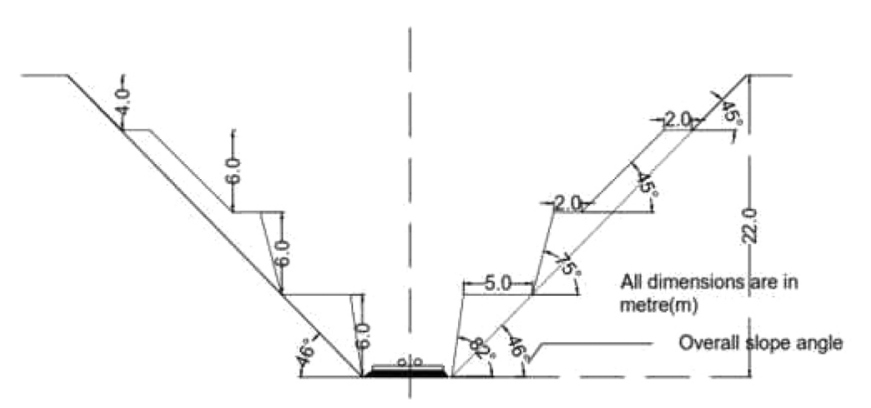

Figure 4. Proposed final cross section of redesign cutting.

(GSI), material constant $\left(m_{i}\right)$ and disturbance factor $(\mathrm{DF})^{18}$. Rocdata software was used to calculate the values of cohesion $(C)$ and angle of internal friction $(\Phi)$.

In addition to kinematic analysis, FDM of analysis was also conducted in stability analysis. The model was prepared considering the highest cut-depth (on the eastern side of the track) and was analysed with FLAC 3D software using Hoek-Brown failure criteria to know the FoS (factor of safety) of slope. FoS is a value that indicates the condition of slope and its vulnerability to failure. FoS value less than 1 indicates slope's susceptibility to failure. Long-term stability can be ensured by increasing the FoS equal to 1.5 (refs 19-21). The slope stability in terms of variation in shear-strain rate was determined to evaluate FoS using numerical modelling. It was found that the failure surfaces developed on the model cutting were almost vertical. The maximum shear strain contour indi- cated the failure all along the cutting face (Figure 3 ). The FoS of the cutting was found to be 0.91 indicating likelihood of failure. To determine the safe slope angle of the cutting before initiating rock excavation, kinematic analyses were carried out. It revealed that no planar and wedge failure would occur if the overall angle of slope is kept as $46^{\circ}$. The proposed cross-section of the redesigned Talegaon II cutting is shown in Figure 4.

\section{Problems associated with blasting in active rail route}

Excavation of slope material to reduce the slope angle from $82^{\circ}$ to $46^{\circ}$ in an active traffic setting needed special attention to ensure punctuality and safety of trains. Initially, a ramp was prepared from a low lying area to reach the top of the cutting. Excavator was used for removing the top soil-boulder mixed strata. However, removal of the oversized boulder and hard rock required systematic drilling and blasting operation. Controlling the throw of the blast was a vital issue, as it would severely damage the track. Moreover, the thrown muck on railway track would require considerable clearance time. Stoppage of trains was not possible for more than $45 \mathrm{~min}$ as demanded by train traffic frequency and this limited the blasting time. Furthermore, a higher magnitude of blastinduced ground vibration would have resulted in slope damage and uncontrolled rockfall. Hence, vibration was to be controlled. 


\section{Methodology}

The aforesaid problems were addressed by designing an innovative sequence of excavations to direct the throw of the blast, control vibration, throw and flyrock within desired limit. After exposing the hard rock surface, benching of $1.5 \mathrm{~m}$ thick layers was planned to excavate the cutting. Further, the entire width of the excavation was divided into two parts. In the first part, controlled blast design was planned to excavate $1.5 \mathrm{~m}$ deep trench, leaving $2 \mathrm{~m}$ wide barrier towards slope face. The aim behind leaving barrier was to direct the throw parallel to the track and to prevent the slippage of blasted material towards the rail track. Apart from the excavation sequence, blast design plays an important role in controlling the throw and blast-induced damages in slopes. Accordingly, blast design parameters such as bore hole diameter, charge per hole $(\mathrm{CPH})$ and maximum instantaneous charge (MIC) were carefully chosen. A larger diameter of hole would generate a higher magnitude of ground vibration, throw, flyrock and overbreak. Therefore, it was decided to use a small drill diameter $(34 \mathrm{~mm})$ and matching explosive diameter $(25 \mathrm{~mm})$ for benching. The other advantage was the mobility of Jack-hammer drills for drilling small diameter holes on uneven topography and in the limited span of working. Specification of the smalldiameter explosive is given in Table 3.

\section{Control of blast-induced vibration}

The blast-induced ground vibrations were to be controlled within the safe limit for rockfall and slope damages. Rock mass properties such as density and $p$-wave velocity play an important role in stress wave propagation for nearfield vibration. However, the rockmass does not vary greatly in the near field. Thus, vibration in the near field is highly influenced by $\mathrm{CPH}$, MIC and distance $(D)$ from the blasting patch. In the present study, cube root scaled distance (SD) was used for predicting near-field peak particle velocity (PPV). It was measured for single hole, multi holes and rows blasting. The vibration was measured at 0.7 to $10 \mathrm{~m}$ distance from the blast patch using uniaxial and tri-axial geophones (capable of measuring

Table 3. Technical specifications of explosive (25 $\mathrm{mm}$ diameter)

\begin{tabular}{ll}
\hline Parameters & \multicolumn{1}{c}{ Range/value } \\
\hline Explosive type & Emulsion \\
Density (g/cc) & $1.2 \pm 0.05$ \\
Relative weight strength & $112 \%$ \\
Relative bulk strength & $161 \%$ \\
Velocity of detonation $(\mathrm{m} / \mathrm{s})$ & $4000 \pm 400$ \\
Sensitivity & No. 6 strength detonator or \\
& detonating cord $(10 \mathrm{~g} / \mathrm{m})$ \\
Water resistance & Excellent \\
\hline
\end{tabular}

2540 and $254 \mathrm{~mm} / \mathrm{s}$ respectively) for plotting attenuation curve for regression analysis by Ambraseys-Hendron ${ }^{22}$. Lucca $^{23}$ also recommended the cube root SD to predict vibration in near-field condition

$$
\mathrm{PPV}=k\left(\frac{D}{\sqrt[3]{\mathrm{MIC}}}\right)^{-b}
$$

where $k$ and $b$ are the site constants.

Regression analysis of 16 data sets was undertaken to determine the site constants ( $k$ and $b$ ) of eq. (1). Measured PPV was plotted against cube root SD on a logarithmic scale (Figure 5). After the determination of site constants $(k: 535.1$ and $b: 1.180)$, the same equation was used for prediction of PPV. Previous studies on the subject $^{24-26}$ for determining PPV to prevent damage in different categories of rock masses are summarized in Table 4. The rocks of Talegaon II cutting come under classes I and II (ref. 27). A review of the standards and measured values suggested that $700 \mathrm{~mm} / \mathrm{s}$ can be considered as safe PPV to prevent radial cracking ${ }^{24,26,28,29}$ and $305 \mathrm{~mm} / \mathrm{s}$ for preventing spalling or fall of rock ${ }^{30}$.

Determination of safe $\mathrm{CPH}$ and MIC for firing a round of blast in trench. The vibration generated from the detonation of blast hole can damage the rock mass up to 20 to 30 times the diameter ${ }^{31,32}$. Considering rock mass strength of the site shown in Table 2 and threshold of PPV in Table 4, the PPV levels with different CPH were calculated using eq. (1) up to a radius of $2 \mathrm{~m}$ (interval of $0.5 \mathrm{~m}$ ) from a blast hole (Table 5). Further, MIC in a

Table 4. Threshold level of PPV for damages in different rock masses

\begin{tabular}{lccc}
\hline Rock type & $\begin{array}{c}\text { Specific gravity } \\
(\mathrm{g} / \mathrm{cc})\end{array}$ & $\begin{array}{c}\text { Compressive } \\
\text { strength }(\mathrm{MPa})\end{array}$ & $\begin{array}{c}\text { PPV } \\
(\mathrm{mm} / \mathrm{s})\end{array}$ \\
\hline Hard rock & $>2.7$ & 240 & 1200 to 2000 \\
Medium hard rock & $>2.5$ & 100 to 150 & 700 to 1000 \\
Soft rock & $>2.3$ & $<50$ & $<400$ \\
\hline
\end{tabular}

PPV, Peak particle velocity.



Figure 5. Regression plot PPV versus cube root SD. 


\section{RESEARCH ARTICLES}

round of blast was also chosen (Table 6) to prevent rock damages. The rock mass slide or rockfall from barrier or facet were prevented by keeping PPV level below $305 \mathrm{~mm} / \mathrm{s}$ at a distance of $2 \mathrm{~m}$ from the blasting source (Table 6).

Trench blast design. The aforesaid threshold levels for $\mathrm{CPH}$ and MIC helped in determining the blast design parameters for trench excavation. The blast design parameters are described in Table 7 and illustrated in Figure 6. After drilling the required depth, each blast hole was charged with cartridge emulsion explosive of $25 \mathrm{~mm}$ diameter and $0.125 \mathrm{~kg}$ weight using detonating cord $(10 \mathrm{~g} / \mathrm{m})$ for initiation. Detonating cord was selected in view of the safety of trains and ease in making the connection. Holes within a row of trench blasting were charged with two cartridges except for corner holes where one cartridge was used in two to three decks as shown in Figure 6. Cord relay $(25 \mathrm{~ms})$ was used to provide a delay between two rows. The direction of firing was kept parallel to the track for controlling the throw at bench level. The aforesaid blasting sequence with small blast geometry, very low powder factor yielded least throw, minimal damages to the redesigned slope and existing slope face. Barrier left towards track prevented blasted muck from collapsing down during trench blasting (as the magnitude of PPV generated was less than $200 \mathrm{~mm} / \mathrm{s}$ at $2 \mathrm{~m}$ distance from the blasting holes). Further, maximum $\mathrm{CPH}$ and $\mathrm{MIC}$ used were 0.25 and $1.75 \mathrm{~kg}$ which resulted in PPV less than $700 \mathrm{~mm} / \mathrm{s}$ at a distance of $1 \mathrm{~m}$.

Barrier blast design. After 20-30 m excavation of a trench, the second part (barrier rock) was removed. The

Table 5. Predicted values of PPV (mm/s) up to $2 \mathrm{~m}$ for different charge per hole

\begin{tabular}{lllll}
\hline & \multicolumn{4}{c}{ Charge per hole $(\mathrm{kg})$} \\
\cline { 2 - 5 }$D(\mathrm{~m})$ & 0.125 & 0.25 & 0.375 & 0.5 \\
\hline 0.5 & 535.1 & 702.8 & 824.4 & 923.1 \\
1.0 & 236.2 & 310.2 & 363.8 & 407.4 \\
1.5 & 146.4 & 192.2 & 225.5 & 252.5 \\
2.0 & 104.2 & 136.9 & 160.6 & 179.8 \\
\hline
\end{tabular}

Table 6. Predicted value of MIC up to radius of $2 \mathrm{~m}$

\begin{tabular}{lcc}
\hline PPV & $700 \mathrm{~mm} / \mathrm{s}$ & $305 \mathrm{~mm} / \mathrm{s}$ \\
$D(\mathrm{~m})$ & $\mathrm{MIC}(\mathrm{kg})$ & $\mathrm{MIC}(\mathrm{kg})$ \\
\hline 0.5 & 0.25 & 0.03 \\
1.0 & 1.98 & 0.23 \\
1.5 & 6.68 & 0.78 \\
2.0 & 15.84 & 1.84 \\
\hline
\end{tabular}

MIC, Maximum instantaneous charge. existing slope facet at most of the places was found to be cracked, fractured and was removed by the excavator. However, in case of a competent barrier, directional controlled blasting utilizing free face towards trench was conducted. Maximum of three rows of holes having smaller blast geometry (depth: $1.5 \mathrm{~m}$; burden: 0.5 to $0.6 \mathrm{~m}$; spacing: $0.6 \mathrm{~m}$ ) were drilled according to barrier width (Figure 7). Differential explosive charging (trench end row holes were charged with $0.25 \mathrm{~kg}$ of explosive and other holes with $0.125 \mathrm{~kg}$ in three decks) was used. Detonating cord $(10 \mathrm{~g} / \mathrm{m})$ was used as a system of ignition within the hole and within a row. The row firing with



Figure 6. Layout of trench blasting with direction of throw.

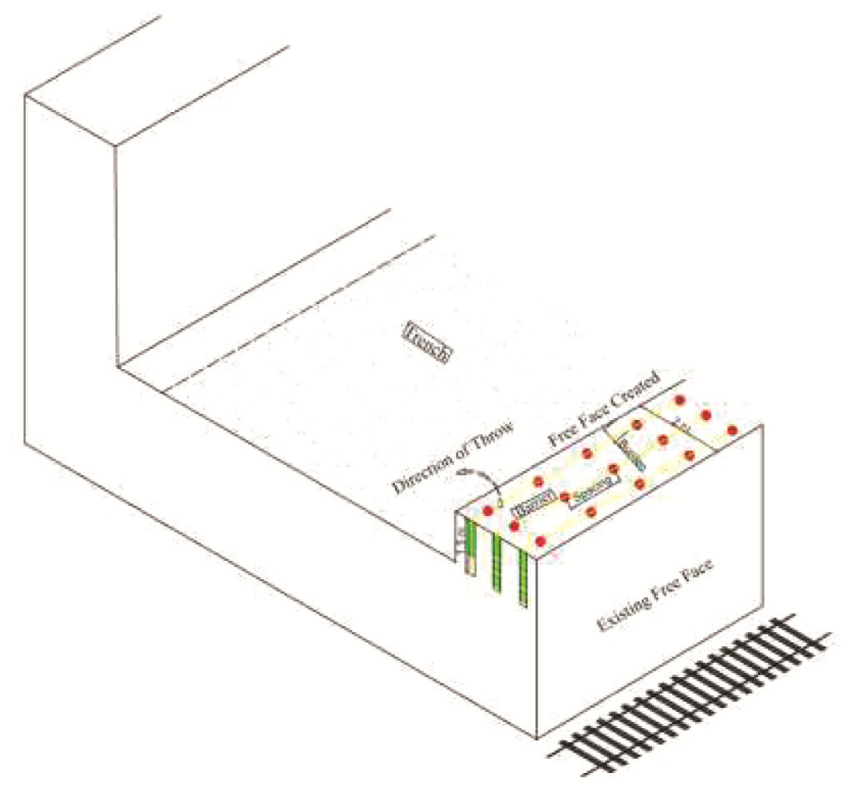

Figure 7. Layout of barrier blasting with direction of throw. 
RESEARCH ARTICLES

Table 7. Blast design parameters for trench blasting

\begin{tabular}{|c|c|c|}
\hline Parameter & Range/value & Cause \\
\hline Depth of hole & 0.75 to $1.5 \mathrm{~m}$ & To control the degree of the throw over the bench and track \\
\hline Blast hole diameter & $34 \mathrm{~mm}$ & To reduce damage zone and to generate fine fragmentation \\
\hline Explosive diameter & $25 \mathrm{~mm}$ & To reduce damage of rock mass, throw, flyrock and rockfall \\
\hline Blast hole inclination & 0 to $5^{\circ}$ & To maintain the bench slope \\
\hline Burden & (0.3 to 0.6$)$ of depth of holes & To minimize throw of the blast and flyrock \\
\hline Spacing & 1 to 1.2 times the burden & To maintain bench floor \\
\hline Deck & Two of 0.2 to $0.3 \mathrm{~m}$ in corner holes & $\begin{array}{l}\text { Optimum distribution of explosive energy to minimize overbreak, back break, } \\
\text { throw and rockfall }\end{array}$ \\
\hline Top stemming & 0.7 to 1.0 times the burden & To stop surface crater formation and flyrock \\
\hline Initiation pattern & Preferably U pattern & To restrict the muck pile length and throw towards track \\
\hline
\end{tabular}

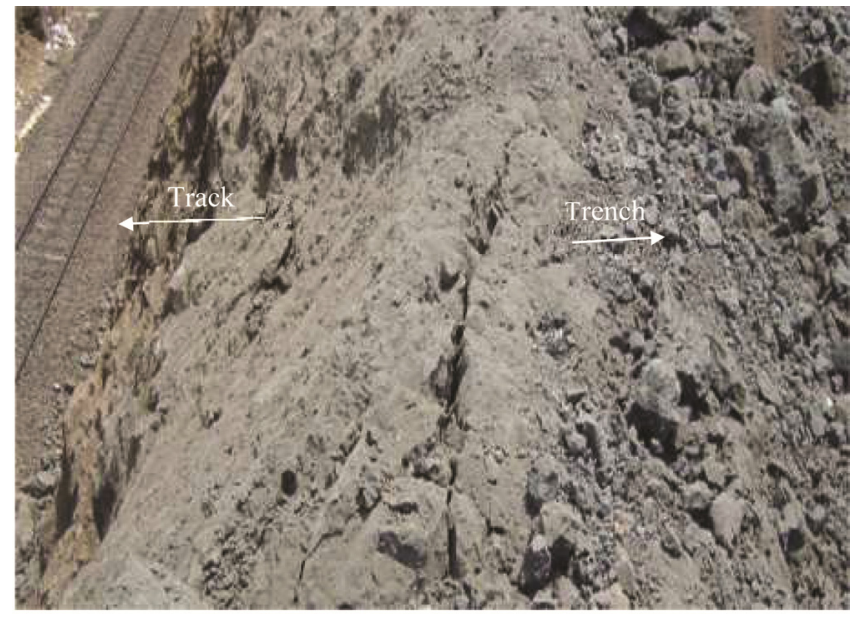

Figure 8. Cracked barrier rock.



Figure 9. Smooth and stable slope after excavation.

a delay of $25 \mathrm{~ms}$ was used to direct the throw towards the trench. Both end row holes (trench and track) were fired instantaneously to instigate the collision of the shock waves for fine fragmentation. Fine fragmentation ensured less impact and damages to the track if the rock fell due to gravity on the track. Further, fine fragments could be easily removed manually from the track quickly. Cracked barrier rock obtained after blasting $\left(0.08 \mathrm{~kg} / \mathrm{m}^{3}\right)$ is shown in Figure 8. It was easily removed by the excavator.

\section{Track protection and timely excavation}

To achieve the excavation of targeted quantity $\left(10,000 \mathrm{~m}^{3}\right.$ of hard rock) within the stipulated time, i.e. two months, minimum two traffic blocks were demanded in a day. Prior to blasting, train movement between adjacent railway stations was stopped for a period of 30 to $45 \mathrm{~min}$. However, heavy traffic on the section posed difficulty in availing a block. After taking the block, muffling of the affected length of the track was done using two to four layers of scrap tyres. During the block time, surface connection between holes and rows was done using a detonating cord and cord relay. After making a connection, one electric detonator was knotted with detonating cord in each blast towards free face to initiate the blast. Further, blasts were taken after sheltering. After blasting, protective covering was removed within block time. The targeted excavation was successfully completed in the desired duration. On an average, $200 \mathrm{~m}^{3}$ of hard rock was removed per day through blasting. The total number of blasts conducted were 106 with the number of holes varying between 1 and 247. The volume of rock blasted varied between 0.8 and $177 \mathrm{~m}^{3}$. The powder factor values varying between 0.08 and $0.25 \mathrm{~kg} / \mathrm{m}^{3}$ yielded in the least movement of fragmented rock towards the rail track as desired. This powder factor is very low compared to the suggested value of powder factor (i.e. more than $0.3 \mathrm{~kg} / \mathrm{m}^{3}$ ) for medium to hard strength rock $^{25}$. However, in three cases, when trimming was done to remove the overhang, blasted muck fell over the track. Muffling using scrap tyres provided ample cushioning to minimize the damage to the track.

The final view of the stable slope is shown in Figure 9. The blast design and sequence of excavation followed were successful and apt, considering geoenvironmental constraints. 


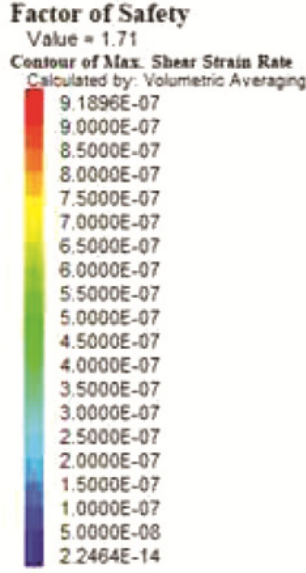



Figure 10. FLAC 3D Model of redesigned slope.

\section{Stability analysis of final slope}

The stability of redesigned slope has been determined in FLAC 3D. The maximum shear strain rate reduced from $1.75 \times 10^{-6}$ in the initial model to $9.19 \times 10^{-7}$ in the final model (Figure 10). Overall, FoS of 1.71 indicated longterm stability. After stabilization, no case of failure has been reported.

\section{Conclusions}

The success of the methodology presented in the study can be useful in effectively implementing the method to widen or stabilize accident-prone slopes in hilly terrains along the transportation routes without closing the traffic. Kinematic analysis can be carried out to finalize the overall slope angle, berm width and bench height. It is suggested that controlled blasting, along active transportation routes, must be divided into two parts, i.e. trench and barrier. First, a trench may be excavated leaving a barrier rock towards a rail track or roadway to control the throw and spread of blasted muck. It is recommended to use small blast geometry with $1.5 \mathrm{~m}$ deep trench blasting for effective control on associated hazards. Further, explosives must be charged in a controlled and distributed manner to prevent the cracking and sliding of slope mass. Explosive charge for controlled blasting in a trench can be determined considering the threshold level of vibration (i.e. $700 \mathrm{~mm} / \mathrm{s}$ ) to prevent cracking and $305 \mathrm{~mm} / \mathrm{s}$ for sliding of the rock mass. The sequence of blasts must be directed perpendicular to the track line or roadway to avoid throw of muck over the track or road. The barrier can be removed mechanically or blasted using directional controlled blasting methodology as described in the study. Protecting muffling with scrap tyres in layers is recommended to prevent damage on railway track or existing road formations for quick restoration of traffic.
Conflict of interest: The authors declare no known conflicts of interest.

1. Peckover, F. L. and Kerr, W. G., Treatment and maintenance of rock slops on transportation routes. Can. Geotech. J., 1977, 14, $487-507$.

2. Umrao, R. K., Singh, R., Ahmad, M. and Singh, T. N., Stability analysis of cut slopes using continuous slope mass rating and kinematic analysis in Rudraprayag district, Uttarakhand. Geomaterials, 2011, 1, 79-87; doi:10.4236/gm.2011.13012.

3. Kainthola, A., Singh, P. K. and Singh, T. N., Stability investigation of road cut slope in basaltic rock mass. Geosci. Frontiers, 2015, 6, 837-845; doi:10.1016/j.gsf.2014.03.002.

4. Singh, P. K., Kainthola, A., Panthee, S. and Singh, T. N., Rockfall analysis along transportation corridors in high hill slopes. Environ. Earth Sci., 2016, 75, 441; doi:10.1007/s12665-016-5489-5.

5. Ersoz, T. and Topal, T., Assessment of rock slope stability with the effects of weathering and excavation by comparing deterministic methods and slope stability probability classification (SSPC). Environ. Earth Sci., 2018, 77, 547; doi:10.1007s12665-018-77284.

6. McCauley, M. L., Works, B. W. and Naramore, S. A., Rockfall mitigation. Report FHWA/CA/TL85/12, FHWA, US Department of Transportation, 1985, pp. 1-147.

7. Casale, M., Oggeri, C. and Peila, D., Improvements of safety conditions of unstable rock slopes through the use of explosives. Nat. Haz. Earth Syst. Sci., 2008, 8, 473-481.

8. Wyllie, D. C., Rock Fall Engineering, CRC Press, 2014, 1st edn; doi:10.1201/b17470.

9. Duncan, C. W. and Norman I. N., Stabilization of rock slopes. Landslide investigations and mitigation. Special Report 247, Transportation Research Board, National Research Council, Washington, 1996, pp. 474-506.

10. Fookes, P. G. and Sweeney, M., Stabilization and control of local rock falls and degrading rock slopes. Quart. J. Eng. Geol. Hydrol., 1976, 9, 37-55; doi:10.1144GSL.QJEG.1976.009.01.03.

11. Kumar, K., Prasad, P. S., Mathur, S. and Kimothi, S., Rockfall and subsidence on Mumbai-Pune Expressway. Int. J. Geo-Eng. Case Hist., 2010, 2(I), 24-39; doi:10.4417/IJGCH-02-01-02.

12. Wyllie, D. C. and Mah, C. W., Rock Slope Engineering: Civil and Mining, Spon Press, New York, 2004, 4th edn, p. 456.

13. Research Design \& Standards Organisation (RDSO), Guidelines for cuttings in railway formations. GE: G-2, Geotechnical Engineering Directorate, Research Designs and Standards Organisation, Government of India, Ministry of Railways, 2005, p. 183. 
14. Shinghal, B. B. S., Hydrogeological characteristics of Deccan trap formations of India, hard rock hydrosystems. In Proceedings of Rabat Symposium S2, May 1997, IAHS Publ No. 241, 1997, pp. $75-79$.

15. Indian Standard: IS:11315 (Part 10), Method for the quantitative descriptions of discontinuities in rock masses, 1987, pp. 1-12.

16. Palmstrom, A., The volumetric joint count - A useful and simple measure of the degree of rock mass jointing. In Proceedings of 4th IAEG, New Delhi, 1982, pp. 221-228.

17. Indian Standard: IS:11315 (Part 5), Method for the quantitative descriptions of discontinuities in rock masses. 1987, pp. 1-16.

18. Hoek, E, Carranza-Torres, C. and Corkum, B., Hoek-Brown Failure Criterion - 2002 edn. In Proceedings of NARMS-TAC, Mining Innovation and Technology, Toronto, University of Toronto, 2002, pp. 267-273.

19. Adams, B. M., Slope stability acceptance criteria for opencast mine design. In 12th ANZ Conference on Geomechanics and Human Influence, Wellington, New Zealand, 2015, pp. 916-923.

20. Canadian Geotechnical Society, Canadian Foundation Engineering Manual, BiTech Publishers Ltd, Vancouver, Canada, 1992.

21. Hoek, E., Practical Rock Engineering, Rocscience, Toronto, 2007, p. 341.

22. Ambrasys, N. R. and Hendron, A. J., Dynamic behavior of rock masses. In Rock Mechanics in Engineering Practice (eds Stagg, K. G. and Zeinkiewicz, O. C.), Wiley, London, 1968, pp. 203-207.

23. Lucca, F. J., Tight construction blasting: ground vibration basics, monitoring and prediction. Terra Dinamica LLC, 2003, 1-21.

24. Holmberg, R. and Persson, P. A., Swedish approach to contour blasting. In Proceedings of 4th Conference on Explosive and Blasting Techniques (ed. Konya, C. J.), Society of Explosives Engineers, New Orleans, Louisiana, 1978, pp. 113-127.

25. Jimeno, C. L., Jimeno, E. L. and Carcedo, F. J. A., Drilling and Blasting of Rocks, A. A. Balkema, Rotterdam, The Netherlands 1995, p. 391.
26. Tsoutrelis, C., Kapenis, A. and Theophili, C., Determination of blast induced damage zones in pillars by seismic imaging. In Proceedings of EXPLO Conference, 1995, pp. 387-393.

27. Barton, N. R., Lien, R. and Lunde, J., Engineering classification of rock masses for the design of tunnel support. Rock Mech., 1974, 6(4), 189-239.

28. Arora, S. and Dey, K., Estimation of near-field peak particle velocity: A mathematical model. J. Geol. Mining Res., 2010, 2(4), 66-73.

29. Rustan, L. N., Controlled blasting in hard intense jointed rock in tunnels. CIM Bull., 1985, 8(884), 63-68.

30. Langefors, U. and Khilstrom, B., The Modern Technique of Rock Blasting, John Wiley, New York, 1973, p. 473.

31. Hustrulid, W. and Johnson, J., A gas pressure-based drift round design methodology. In Proceedings of the 5th International Conference on Mass Mining (eds Schunnesson, H. and Nordlund, E.), Lulea University of Technology Press, Lulea, Sweden, 2008, pp. 657-669.

32. Konya, C. J. and Walter, E. J., Rock blasting. In Seminar of Blasting and Overbreak Control, Precision Blasting Services, Montville, $\mathrm{OH}, 1985$.

ACKNOWLEDGEMENTS. We thank all the concerned officers of Konkan Railway Corporation and associated contractors for providing necessary facilities during field investigations. The permission of competent authority of CSIR-Central Institute of Mining and Fuel Research, Dhanbad, India to publish the paper is thankfully acknowledged.

Received 21 August 2019; revised accepted 30 December 2019

doi: $10.18520 /$ cs/v118/i6/901-909 